
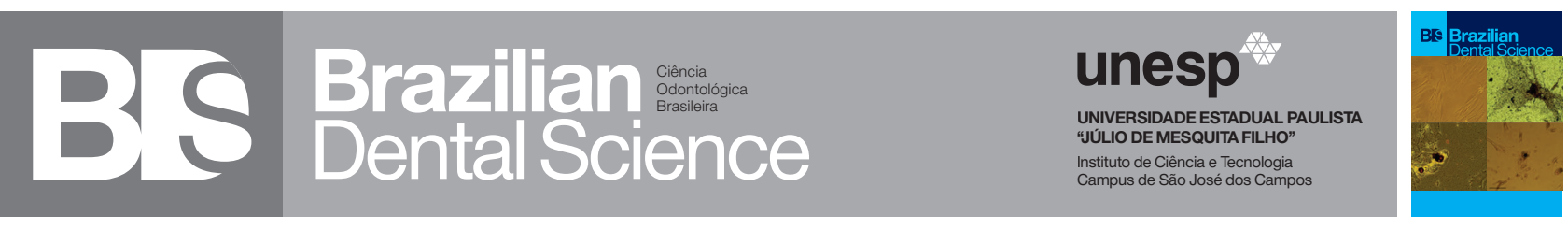

\title{
Diagnostic accuracy of dental pulse oximeter with customized sensor holder, thermal test and electric pulp test for the evaluation of pulp vitality: an in vivo study
}

Precisão diagnóstica do oxímetro de pulso odontológico com suporte de sensor personalizado, teste térmico e teste elétrico da polpa para avaliação da vitalidade pulpar: um estudo in vivo

Krishnamachari JANANI ${ }^{1}$, Ajitha PALANIVELU', Raghu SANDHYA ${ }^{1}$

1 - Saveetha Dental College and Hospital - Department of Conservative Dentistry and Endodontics - Chennai - Tamil Nadu - India.

\begin{abstract}
Background: the efficiency of the diagnostic aids plays an important role in the treatment plan. This study aims to assess the diagnostic accuracy of dental pulse oximeter with a customized sensor holder, thermal test and electric pulp tester in assessing the actual pulp status and to evaluate the oxygen saturation level in control healthy teeth, non-vital and teeth with irreversible pulpitis. Material and methods: thirty-seven single canal teeth requiring endodontic therapy were included in the study. The selected teeth were tested with dental pulse oximeter, electric pulp test, cold spray, and heated gutta percha stick. Between each test a time lag of 2 minutes was allowed for the central sensitization to occur. Three blinded operators were involved in the study. The actual status of the pulp was evaluated after the initiation of endodontic treatment, by direct visual examination of the accessed cavity. The data was statistically analysed using (ANOVA) Analysis of Variance and Post-hoc Tukey test. Results: sensitivity of pulse oximeter, heat test, cold and electric pulp test, was $100,25,50$, and 12 , respectively. The specificity of these tests was 100, 72 81, and 77, respectively. The ANOVA showed that there was statistical difference between all the groups $(p=0.0005)$. Post-Hoc Tukey revealed that there was statistical difference among all the groups, nonvital group $(p=0.0005)$, control group $(p=0.01)$ and for irreversible pulpitis $(\mathrm{p}=0.01)$. The overall diagnostic accuracy of pulse oximeter was $100 \%$ followed by cold test $66 \%$, heat test to be $49 \%$ and electric pulp test to be 45\%. Conclusion: the custom-made holder used in the present study aided in providing accurate response for pulp vitality testing. In this study the diagnostic accuracy was high with dental pulse oximeter followed by cold, heat and the least was electric pulp tester in different pulpal conditions.
\end{abstract}

\section{KEYWORDS}

Cold test; Heat test; Oxygen saturation; Pulse oximeter; Vitality tests.

\section{RESUMO}

Fundamentação: a eficiência dos meios de diagnóstico desempenha um papel importante no plano de tratamento. Este estudo tem como objetivo avaliar a precisão diagnóstica do oxímetro de pulso odontológico com um suporte de sensor personalizado, teste térmico e testador de polpa elétrico na avaliação da condição pulpar e na avaliação do nível de saturação de oxigênio em dentes controle saudáveis, não vitais e dentes com pulpite irreversível. Material e métodos: trinta e sete dentes de canal único que necessitavam de terapia endodôntica foram incluídos no estudo. Os dentes selecionados foram testados com oxímetro de pulso, teste pulpar elétrico, spray frio e bastão de guta-percha aquecido. Entre cada teste, foi permitido um intervalo de tempo de 2 minutos para a sensibilização central ocorrer. Três operadores cegos foram envolvidos no estudo. A condição real da polpa foi avaliada após o início do tratamento endodôntico, por meio de exame visual direto da cavidade de acesso. Os dados foram analisados estatisticamente pelo teste de Análise de Variância (ANOVA) e pelo teste Post-hoc de Tukey. Resultados: a sensibilidade do oxímetro de pulso, teste de calor, de frio e teste pulpar elétrico foi de 100, 25, 50 e 12, respectivamente. A especificidade desses testes foi de 100, 7281 e 77, respectivamente. O teste de ANOVA mostrou que houve diferença estatística entre todos os grupos ( $\mathrm{p}=0,0005)$. O teste Post-Hoc de Tukey revelou que houve diferença estatística entre todos os grupos, grupo não-vital ( $p=0,0005)$, grupo controle $(p=0,01)$ e pulpite irreversível $(\mathrm{p}=0,01)$. A precisão diagnóstica geral do oxímetro de pulso foi de $100 \%$, seguida pelo teste a frio de $66 \%$, o teste de calor a $49 \%$ e o teste pulpar elétrico a $45 \%$. Conclusão: o suporte personalizado utilizado no presente estudo ajudou a fornecer uma resposta precisa para o teste de vitalidade pulpar. Neste estudo, a precisão diagnóstica foi alta com o oxímetro de pulso dental, seguido do teste com frio e calor, sendo o teste elétrico o menos eficaz nas diferentes condições pulpares testadas.

\section{PALAVRAS-CHAVE}

Teste de frio; Teste de calor; Saturação de oxigênio; Oxímetro de pulso; Testes de vitalidade. 


\section{INTRODUCTION}

D ulp vitality plays an important role 1 in routine dental practice [1]. Pulp vitality tests are the valuable diagnostic tool which aids the clinician towards the accurate diagnosis and appropriate treatment planning. Diagnosing the exact pulpal status by direct examination is uncertain due to the fact that the pulp is enclosed within a hard tissue. In order to identify the actual pulp status surrogate test must be performed [2]. Though commonly named as pulp vitality test, some tests record the neural response of the tooth and rely on subjective response of pain perceived by the patient. Hence the appropriate term which has been used is pulp sensibility test [3].

Disease of the pulp can be infectious or inflammatory. In such conditions, the healthy pulp attempts to counteract the inflammatory response as a defence mechanism in order to restore the integrity of the pulp [4]. Therefore, the presence of blood flow within the pulp is a reliable indicator as it can reflect the degree of pulpal disease. The tests which record the blood flow within the pulp are termed as pulp vascularity tests as it is the only true indicator in assessing the actual pulp status [5]. The nervous tissue being highly resistant to inflammation may remain reactive long after the surrounding tissues have degenerated. In such conditions pulp sensibility shows a false positive response. The other drawback of pulp sensibility tests is that false negative response encountered in tooth that has undergone trauma [6] wherein the sensory nerve fibers are temporarily disabled but the micro circulation within the pulp is still normal [7].

Recently attempts were made to determine the pulpal circulation owing to the above-mentioned limitations. The devices which record the pulp vascularity response include Laser Doppler flowmetry, Dual Wavelength Spectrophotometry and Pulse Oximetry. The use of laser doppler flowmetry in endodontic practice has been hindered due to lack of reproducibility, expensive cost and less sensitivity of the device [1]. The shortcomings of dual wavelength spectrophotometry are that it can detect the presence of haemoglobin quantitatively but the circulation of blood within the pulp cannot be detected [8].

Takuo Aoyagi, a biomedical engineer working for the Shimadzu Corporation in Kyoto, Japan, invented pulse oximeter in early 1970's. It was primarily used in medical field for recording the oxygen saturation levels by placing the sensor probe on finger, toe and ear [9].

Pulse oximeter works on the principle of Beer Lamberts law. It consists of two light emitting diode which emits red light $(640 \mathrm{~nm})$ and infrared light $(940 \mathrm{~nm})$. On the opposite side of the vascular bed, a photodetector is present. Infra-red and red light gets absorbed at different amounts by oxygenated and deoxygenated haemoglobin. The pulsatile change in the blood volume causes periodic changes in the amount of red infrared light absorbed by the vascular bed before reaching the photodetector. The relationship between the pulsatile change in the absorption of red light and the pulsatile change in the absorption of infrared light is analysed by the pulse oximeter to determine the saturation of arterial blood.

Recently, studies were done to detect the oxygen saturation of the pulp using pulse oximeter. The novelty and originality in the present study was to customize a dental pulse oximeter sensor holder which adapts within the mesiodistal dimensions of the tooth and developed pulse oximeter sensor holder using 3D printing in such way that the parallelism is maintained between the sensor and photodetector when placed on the tooth. In transmission mode of pulse oximeter, the light source and photodiode are opposite to each other. As the light passes through the site it gets detected by photodetector. This is the reason for maintenance of parallelism.

Therefore, the aim of the study was to aims to assess the accuracy of dental 
pulse oximeter with a customized sensor holder, thermal test and electric pulp tester in assessing the actual pulp status and to evaluate the oxygen saturation level in control healthy teeth, non-vital and teeth with irreversible pulpitis. Oxygen saturation level was recorded from finger and was kept as reference standard.

\section{MATERIAL AND METHODS}

This study included patients with 18 to 50 years of age from whom 37 single-canal teeth were tested. Incisors, canine and mandibular premolar teeth requiring endodontic treatment were included in the study. The presence of only one canal was confirmed by two periapical radiographs taken in both the mesiodistal and buccolingual directions. Before initiating the pulp tests, all patients were apprised of the aim of the study and signed the informed consent form. The research protocol was approved by the Ethical Committee of (SRB/ SD MDS11/170DS/11). Single rooted teeth requiring root canal treatment, traumatized teeth and teeth with deep carious lesions with history, clinical, radiographic changes indicative of irreversible pulpitis were included in the study. Out of total 37 single rooted teeth, 7 patients reported with the history of trauma within the period of month, 10 patients presenting with deep caries were included the study. Patients with systemic disease or drug consumption including analgesics, narcotics, tranquilizers, sedatives, and alcohol were excluded from the study.

Three blinded operators were involved in the study. For each patient, clinical history and radiographic examination were performed by the first operator. The second operator performed pulp sensibility tests which included heat test using heated gutta percha stick, cold test using 1, 1, 1, tetrafluoroethene and with digital electric pulp tester which was tested on the middle third of the labial surface of the tooth. The third blinded operator performed the pulp vascularity test using dental pulse oximeter. The order of pulp testing was started with heat test, cold test, electric pulp test and dental pulse oximeter. Patient was positioned in seated posture when the pulp test was performed rather than lying down posture, as it may exacerbate the symptoms in case of irreversible pulpitis. A time lag of two minutes was allowed between each pulp tests for the central sensitization to occur. All the pulp tests were repeated to ensure the accuracy of the response.

\section{Heat test}

Following isolation and drying the tooth a layer of vaseline was smeared on the labial surface of the tooth to avoid sticking of gutta percha to the surface. One end of the gutta percha stick was heated on flame out of the subject's sight to the point till it was softened and just began to glisten. Heated gutta percha stick was gently applied on middle - third of the labial surface for 10 seconds

\section{Cold test}

Cold test was performed with double ended ear bud sprayed with 1, 1, 1, tetrafluoroethene (Endo ice refrigerant spray, Coltene/Whaledent Inc., Mahwah, NJ) outside the range of subject's vision. The bud was held back until it was frosty with the maximum of 7 seconds, following which, it was applied on the middle third of the labial surface of the teeth and the response of teeth was recorded

\section{Electric pulp tester}

The electric test was performed by using a digital pulp tester (DigitestTM II Pulp Vitality Tester, Parkell Electronics Division, Farmingdale, NY). The contra lateral tooth was considered as the control. When using the Vitality Scanner, the tooth surface was air dried and isolated by cotton rolls to prevent false responses from the surrounding soft tissues. The special lip clip was attached to the lip, and the electrode was placed on the middle third of the buccal surface. Any pain was recorded as a positive response, whereas no pain at even maximum degrees was recorded as a negative 
response. On performing pulp sensibility tests the response expressed by the subject was Visual Analogue Scale was recorded.

\section{Pulse oximeter}

Pulp vascularity test was performed using dental pulse oximeter. pulse oximeter monitor (Nellcor N-600 Healthcare group LP, Pleasanton, CA) was used in this study. It has a proprietary algorithm to evaluate parameters programmed into the memory chip of the particular sensor being used and current signal characteristics coming from the patient. Sensor (N3 oxy sensor, Healthcare group LP, Pleasanton, CA) was selected, as the dimensions of this sensor were smaller than the mesiodistal dimensions of human permanent dentition. Dental pulse oximeter sensor holder was designed and custom made to ensure accurate placement and adaptation of the sensor on human permanent teeth. Dental pulse oximeter holder was custom made by 3D printing.

$3 \mathrm{D}$ printing is an adaptive manufacturing process whereby lying down the material layer by layer object can be created. Using a computer, the design of the object was created as first step, after which it is sent to the printer. The design gets sliced into a number of layers with the thickness of $0.1 \mathrm{~mm}$. Printer creates an object from that design. Here the scanner scans the design and the laser beams fall onto the powdered bed surface, it creates the cross- sectional area upon that layer after completing the first layer platform lowered by $0.1 \mathrm{~mm}$ and another layer of powder is to be distributed over it and the process is repeated until the object is created.

Reading for oxygen saturation was noted on the index finger of each subject which was kept as a reference for comparing the readings obtained on teeth. Probe holder was modified such that it fits closely to the tooth surface when placed on the middle third of the crown. Care was taken to place the sensor and the photodetector was placed parallel to each other. This parallelism was achieved by the customized dental pulse oximeter probe holder. Each tooth was evaluated for 30 seconds following which the readings were recorded

Once all the pulp vitality test was completed, access cavity was prepared under rubber dam isolation. The actual status of pulp was recorded by direct visualization of access cavity for the presence or absence of bleeding from the root canal orifice which was considered as the standard reference for this study. Presence of bleeding from the canal orifice was considered to be vital teeth and absence of bleeding was considered to be non-vital teeth. If there was any doubt in direct visualization such teeth were excluded from the study.

\section{Statistical analysis}

IBM.SPSS statistics software 23.0 Version was used to analyse the collected data. To describe the data descriptive statistics frequency analysis, percentage analysis was used for categorical variables and the mean \& S.D were used for continuous variables. To assess the relationship between the variables Pearson's Correlation was used and for assessing the efficacy sensitivity, specificity, positive predictive value and negative predictive value was used. The probability value of .05 is considered as significant level.

\section{RESULTS}

Out of the thirty-seven teeth included in this study, 7 teeth that had undergone trauma. the oxygen saturation reading for these teeth showed the pulp condition to remain vital. These patients were followed up for the period three to six months, following which the Pulp sensibility test showed vital response. Of the remaining 30 teeth, 22 were non-vital and 8 teeth with irreversible pulpitis.

The sensitivity, specificity, positive predictive value, and negative predictive value were calculated for each pulp test (Table 1). The overall accuracy for dental pulse oximeter was $100 \%$ followed by cold test and heat test which was $66 \%$ and $49 \%$ respectively and the least was electric pulp tester with the overall accuracy of $45 \%$. 
The mean oxygen saturation values for experimental groups (teeth) and control group (finger) were tabulated (Table 2). The oxygen saturation readings obtained from teeth was lower when compared to finger. The reason for decreased oxygen saturation justifies that, the light gets diffracted from enamel and dentin. Non vital teeth showed the least oxygen saturation reading compared to irreversible pulpitis and healthy tooth. Analysis of variance revealed that there was statistical difference between all the groups ( $\mathrm{p}$ value 0.0005) (Table 3). Further Tukey post hoc test revealed that there was a statistical difference between nonvital $p$ value 0.0005 and control tooth with $\mathrm{p}$ value of 0.01 and for teeth with irreversible pulpitis of 0.01 (Table 4).

Table 1 - Sensitivity and specificity of pulp vitality test

\begin{tabular}{|ccccc|}
\hline Parameter & $\begin{array}{c}\text { Pulse } \\
\text { oximeter }\end{array}$ & Heat test & Cold test & $\begin{array}{c}\text { Electric } \\
\text { pulp } \\
\text { tester }\end{array}$ \\
\hline Sensitivity & 100 & 25.00 & 50.00 & 12.50 \\
\hline $\begin{array}{c}\text { Specificity } \\
\text { Positive predictive } \\
\text { value }\end{array}$ & 100 & 72.73 & 81.82 & 77.27 \\
\hline $\begin{array}{c}\text { Negative predictive } \\
\text { value }\end{array}$ & 100 & 25.00 & 50.00 & 16.67 \\
\hline \begin{tabular}{c} 
Overall accuracy \\
\hline
\end{tabular} & 100 & 48.86 & 61.82 & 70.83 \\
\hline
\end{tabular}

Table 2 - Oxygen saturation level of dental pulse oximeter in tooth and finger

\begin{tabular}{|c|c|c|}
\hline Group & $\begin{array}{l}\text { Mean oxygen } \\
\text { saturation level } \\
\text { (tooth) }\end{array}$ & $\begin{array}{l}\text { Mean oxygen } \\
\text { saturation level } \\
\text { (finger) }\end{array}$ \\
\hline Non vital & 72.27 & 98 \\
\hline Control tooth & 88.6 & 98 \\
\hline Irreversible pulpitis & 81.88 & 98 \\
\hline
\end{tabular}

Table 3 - Analysis of variance test

\begin{tabular}{|cccccccccc} 
Group & N & $\begin{array}{c}\text { Std } \\
\text { dev }\end{array}$ & $\begin{array}{c}\text { Std } \\
\text { error }\end{array}$ & $\begin{array}{c}\text { Between } \\
\text { group }\end{array}$ & Lower & Lowner & Mound & $\begin{array}{c}\text { Mini- } \\
\text { mum }\end{array}$ & $\begin{array}{c}\text { Maxi- } \\
\text { mum }\end{array}$ \\
\hline $\begin{array}{c}\text { Non } \\
\text { vital }\end{array}$ & 22 & 4.842 & 1.032 & 0.0005 & 70.13 & 74.42 & 59 & 81 \\
$\begin{array}{c}\text { Control } \\
\text { tooth }\end{array}$ & 22 & 5.525 & 1.178 & 0.0005 & 86.79 & 91.09 & 74 & 94 \\
$\begin{array}{c}\text { Irrever- } \\
\text { sible } \\
\text { pulpitis }\end{array}$ & 8 & 6.468 & 2.287 & 0.0005 & 76.47 & 87.28 & 71 & 94 \\
\hline
\end{tabular}

Table 4 - Post Hoc Tukey Test

\begin{tabular}{|ccccc|}
\hline Group & Mean & Std error & $\begin{array}{c}\text { Signifi- } \\
\text { cance }\end{array}$ \\
\hline No vital & $\begin{array}{c}\text { Control } \\
\text { tooth } \\
\text { Irreversible } \\
\text { pulpitis }\end{array}$ & -16.3 & 1.6 & 0.0005 \\
\hline Control & $\begin{array}{c}\text { Non vital } \\
\text { Irreversible } \\
\text { pulpitis }\end{array}$ & 16.3 & 2.2 & 0.0005 \\
\hline Irreversible \\
pulpitis & $\begin{array}{c}\text { Non vital } \\
\text { Control } \\
\text { tooth }\end{array}$ & -6.7 & 2.2 & 0.000 \\
& -6.7 & 2.2 & 0.011 \\
\hline
\end{tabular}

\section{DISCUSSION}

An objective differentiation between vital and necrotic pulp tissue can be detected by blood circulation. To detect blood circulation in the clinical setting, the development of a non-invasive method of detecting circulation is required. In recent years, attempts were made to develop a method for optical determination of pulpal circulation [10].

Although there are several studies published regarding the use of pulse oximeter, it has not become a routine and seems to be in very limited use for clinical evaluation. The reason because the probe and holder still require modification in it. Therefore, the search was focused on the design of the dental pulse oximeter sensor holder which would adapt to the tooth surface

Since reproducible oxygen saturation values are obtained using pulse oximeter, it has immediate clinical value by providing baseline clinical data for traumatized teeth. Immediately after injury, teeth often do not respond to conventional pulp testing methods. This temporary loss of response is caused by injury, inflammation, pressure, or tension on the nerve fibers in the apical area because of trauma [11]. A normal pulpal response can be elicited after the time lapse of 1 to 8 weeks. However, greater observation periods may be required [12].

Most studies did not include a gold 
standard in their study [5,6,13-19]. In order to assess the reliability of the study, the pulp vitality should be confirmed with a reference standard. In the present study direct visualization of bleeding from the canal orifice during access cavity preparation was considered as the standard reference.

The main aim of this study was to design a dental pulse oximeter sensor holder which aid in the accurate assessment of actual pulp status. The dental pulse oximeter is not commercialized though there were previous studies on the use of custom-made dental pulse oximeter probes. This attributes to very limited use of pulse oximeter for clinical evaluation. Noblett et al [3] used a rubber dam clamp as the pulse oximeter sensor holder. Kahan et al [20], Goho [14], and Gopikrishna et al [1, 6] used innovative probes in their studies. In the present study, the customized probe holder was fabricated such that it can well adapt within the mesiodistal dimension of the tooth.

An obvious difference in the results of the present study and some other studies is the efficacy of dental pulse oximeter, thermal and electric tests in determining the pulp vitality. Gopikrishna et al [6] showed that the sensitivity of the pulse oximeter is 1 , the cold test is 0.81 , and the electric test is 0.71 , whereas the specificity of these tests was $0.95,0.92$, and 0.92 , respectively. Also, Karayilmaz and Kirzioglu [21] indicated that the sensitivity of the pulse oximeter was 0.81 and the electric test was 0.91, whereas the specificity of these tests was 0.94 and 0.88 , respectively. Petersson et al [22] also showed that the sensitivity of the heat test was 0.86 , the cold test was 0.83 , and the electric test is 0.72 whereas the specificity of these tests was $0.41,0.93$, and 0.93 , respectively. The results of the present study were not in corroboration with the previous studies as the sensitivity and specificity of thermal test and electric pulp tester differ in values and the overall accuracy in identifying the actual pulpal status was least with heat test. The probable reason for low sensitivity values for pulp sensibility test may be due several factors as the pulp vitality interpretation mainly depends on the patient subjective response to pain. Moreover, the three blinded operators involved in this study performed their pulp testing being unaware of other findings. This might be a significant importance in reducing review bias. The other reason to justify the results of the present study where the direct inspection of dental pulp was kept as reference standard to be compared with pulp sensibility tests and dental pulse oximeter which aided in appropriate results. In the present study electric pulp test showed the least sensitivity when compared to other sensibility test (thermal test), this is due to the fact that compared to $c$ fibers, A delta fibers gives more reliable interpretation of oxygen depletion of pulp.

On assessing the oxygen saturation reading, in case of irreversible pulpitis may be due to increased acidic $\mathrm{pH}$ and metabolic rate causing deoxygenation of haemoglobin. This attribute to the decreased oxygen saturation levels when compared to healthy teeth. In case of necrotic pulp, there is still some amount of remanant blood flow which corresponds to oxygen saturation level. Therefore, it can be reported that, the oxygen saturation readings are inversely proportional to pulpal inflammation.

According to Ozcelik et al. [23], early neuronal degeneration in cases of trauma is manifested as intramyelin oedema, axonal swelling, and partial loss of myelin sheaths. Bhaskar and Rappaport [24] reported their clinical observation on 25 anterior teeth that had been traumatized and did not respond to conventional vitality tests. When the teeth were opened into pulp chambers, all revealed vital pulps. They concluded that conventional vitality tests are in reality sensitivity tests and have questionable predictive value of the vitality of pulp tissue. For this reason, they recommended that endodontic therapy should be delayed on traumatized teeth, and the affected pulp tissue should be considered vital unless apical radiolucency or sinus tracts 
develop. A more accurate assessment of pulp vitality would be made by determining the presence of a functioning blood supply, thus allowing the healing potential to be evaluated at an earlier stage. Moreover, delay in diagnosis can lead to severe complications such as inflammatory root resorption [25]. Therefore, in such cases it is important to identify the status of pulp in order to initiate root canal treatment. Apart from all these, Patient's gender, teeth with periapical pathology, the medical health status of the patient also play an important role in influencing the results of the study $[26,27]$.

As the limitation of the study Background absorption associated with venous blood and tissue constituents might affect the interpretation of result when it comes into contact.

\section{CONCLUSION}

The present study concludes that with the use of custom-made holder, it is effective in ease of placement of sensor probe on to the tooth surface. It aided in evaluating the actual pulp status by producing accurate interpretation of result. Especially in recently traumatized permanent teeth in which temporary paraesthesia of nerves reduces the effectiveness and reliability of thermal and electric pulp testing methods. In such condition, the treatment plan can be decided using dental pulse oximeter. Consistent pulse oximeter readings in this study confirm that pulp circulation and blood oxygen saturation can be detected by the pulse oximeter.

\section{REFERENCES}

1. Gopikrishna V,Kandaswamy D, Tinagupta K. Assessment of the efficacy of an indigenously developed pulse oximeter dental sensor holder for pulp vitality testing-an in vivo study.Ind J Dent Res. 2006;17:111-3.

2. Levin LG. Pulp and periradicular testing.J Jendod. 2013 Mar;39(3 Suppl):S13-9. doi: 10.1016/j.joen.201211.047.

3. Noblett WC, Wilcox LR, ScammanF, Johnson WT, Diaz-Arnold A. Detection of pulpal circulation in vitro by pulse oximetry.JEndod 1996;22:1-5. doi:10.1016/ S0099-2399(96)80226-3.
4. Baumgardner KR, Walton RE, Osborne JW, Born JL. Induced hypoxia in rat pulp and periapex demonstrated by $3 \mathrm{H}$-misonidazole retention. J Dent Res. 1996; 75:1753-60. doi: 10.1177/00220345960750100801.

5. Calil E,Caldeira CL, Gavini G, Lemos EM. Determination of pulp vitality in vivo with pulse oximetry. Int Endod J. 2008 Sep;41(9):741-6. doi: 10.1111/.13652591.2008.01421.x

6. Gopikrishna V, Tinagupta K, Kandaswamy D. Evaluation of efficacy of a new custom-made pulse oximeter dental probe in comparison with the electrical and thermal tests for assessing pulp vitality. JEndod 2009;33: 411-4. doi: 10.1016/j.joen.2006.12.003

7. Bhaskar SN, RappaportHM. Dental vitality tests and pulp status. J Am Dent Assoc. 1973Feb;86(2):409-11. doi: 10.14219/jada.archive.1973.0081.

8. Nisson R, Trope M, Zhang CD, Chance B. Dual wavelength spectrophotometry as a diagnostic test of the pulp chamber contents. Oral Surg 1992; 74:508-14. doi: 10.1016/0030-4220(92)90304-9.

9. Salyer JW. Neonatal and pediatric pulse oximetry. Respir Care.2003 Apr;48(4):386-96; discussion 397-8.

10. Foreman PC. Ultraviolet light as an aid to endodontic diagnosis. Int Endod J 1983;16:121-6. doi: 10.111//.j365-2591.1983.tb01310.x.

11. Andreasen FM, Andreasen JO. Luxation injuries. In: Andreasen FM, Andreasen J0, eds. Textbook and Color Atlas of Traumatic Injuries to the Teeth. 3rd ed. Copenhagen:Munksgaard; 1994. p. 353-4.

12. Schnettler JM, Wallace JA. Pulse oximetry as a diagnostic tool of pulpal vitality. JEndod. 1991;17:488-90. doi:10.1016/S0099-2399(06)81795-4

13. Goho C. Pulse oximetry evaluation of vitality in primary and immature permanent teeth. Pediatr Dent. 1999 Mar-Apr;21(2):125-7.

14. Mumford JM. Evaluation of gutta-percha and ethyl chloride in pulp-testing. $\mathrm{Br}$ Dent J 1964;116:338-42.

15. Fuss Z, Trowbridge H, Bender IB, Rickoff B, Sorin S. Assessment of reliability of electrical and thermal pulp testing agents. J Endod. 1986;12:301-5.

16. Anusha B, MadhusudhanaK, Chinni SK, Paramesh Y. Assessment of Pulp Oxygen Saturation Levels by Pulse 0ximetry for Pulpal Diseases-A Diagnostic Study. JClin Diagn Res. 2017 Sep;11(9):ZC36-ZC39. doi:10.7860/ JCDR/2017/2832210572

17. Munshi A, Hegde A, Radhakrishnan S. Pulse oximetry: a diagnostic instrument in pulpal vitality testing.J Clin Pediatr Dent. 2002 Winter;26(2):141-5.

18. Sadique M, Ravi SV, Thomas K, Dhanapal P,Simon EP, Shaheen M. Evaluation of efficacy of a pulse oximeter to assess pulp vitality. J Int Oral Health. 2014 Jun;6(3):70-2.

19. Kahan RS, GulabivalaK, Snook M, Setchell DJ. Evaluation of a pulse oximeter and customized probe for pulp vitality testing.J Endod. 1996;22(3):105-9. doi: 10.1016/S0099-2399(96)80283-4.

20. KarayilmazH, Kirzio glu Z. Comparison of the reliability of laser Doppler flowmetry, pulse oximetry and pulp tester in assessing the pulp vitality of human teeth. J Oral Rehabil. 2011 May;38(5):340-7. doi: 10.1111/j.13652842.2010.02160.x.

21. Petersson K, $\subseteq €$ oderstr $€$ om C, Kiani-Anaraki M, L evy G. Evaluation of the ability of thermal and electrical tests to register pulp vitality. Endod Dent Traumatol 1999; 15:127-31.

22. Andreasen FM, Andreasen J0. Crown fractures. In: Andreasen FM, Andreasen J0, eds. Textbook and Color Atlas of Traumatic Injuries to the Teeth. 3rd ed. Copenhagen:Munksgaard; 1994.245p.

23. Ozcelik B, Kuraner T, Kendir B, Asan E. Histopathological evaluation of the dental pulps in crown fractured teeth. J Endod 2000;26:271-3. 
24. Bhaskar SN, RappaportHN. Dental vitality tests and pulp status. J Am Dent Assoc. 1973 Feb;86(2):409-11.

25. Tronstad L. Root resorption - etiology, terminology and clinical manifestations. Endod Dent Traumatol. 1988 Dec;4(6):241-52.
26. Jafarzadeh H, Abbott PV. Review of pulp sensibility tests. Partl:genera information and thermal tests. Int Endod J. 2010 Sep;43(9):738-62. doi: 10.1111/.j.1365-2591.2010.01754.X.

27. Jafarzadeh H, Abbott PV. Review of pulp sensibility tests. Part ll: electric pulp tests and test cavities. IntEndod J. 2010 Nov;43(11):945-58. doi:10.1111/j.13652591.2010.01760.x.

\section{Ajitha Palanivelu}

\section{(Corresponding address)}

Saveetha dental college and hospital

162, Poonamallee High Rd, Velappanchavadi, Chennai, Tamil Nadu 600077, Índia

Date submitted: 2019 May 07

E-mail: ajitharijesh@gmail.com 